\title{
Pengaruh Earning Per Share Terhadap Harga Saham Perusahaan Manufaktur Sektor Barang Konsumsi yang Terdaftar Di Bursa Efek Indonesia Periode 2015-2018
}

\author{
Mikha Q. H. M. Mantik \\ Dolina L. Tampi \\ W. S. Manoppo \\ Jurusan Ilmu Administrasi, Program Studi Administrasi Bisnis \\ Fakultas Ilmu Sosial dan Politik. Universitas Sam Ratulangi \\ mikhaqueenhill@gmail.com
}

\begin{abstract}
This research aims to test the partially influence, direction, and the significance of EPS against stock prices in the sector of consumer goods manufacturing company listed in IDX 2015-2018 Period. Financial information functions as a means of information, management accountability tool to the owner of the company, success indicators against the depiction of the company and as a material consideration in decision making. One of the indicators measuring share price i.e.: Earning Per Share. Earnings Per Share (EPS) to measure the company's ability to generate profits per shares. And the stock price is the closing price of the stock market during the period of observation for each type of stock. This research method is associative causal. Of the total population, conducted the withdrawal of samples as many as 29 companies with purposive sampling method, a sampling method that takes an object with certain criteria. Data analysis was done of simple linear regression analysis and hypothesis testing using the analysis of the coefficient of determination and test results showed $t$. EPS positive and significant effect against the price of the shares, with a value of the coefficient of determination $\left(R^{2}\right) 0.435$ and value 0.000 probability less than 0.05 . Based on the results of test data analysis research, it can be seen that the level of variable earnings per shares or Earning Per Share (EPS) have a positive influence significantly to stock prices in the sector of consumer goods manufacturing company in Indonesia Stock Exchange.
\end{abstract}

Keywords: Earning Per Share, Stock Price

\section{Pendahuluan}

Investasi adalah komitmen atas sejumlah dana atau sumber daya lainnya yang dilakukan pada saat ini, dengan tujuan memperoleh sejumlah keuntungan di masa datang (Tandelilin, 2010). Investasi ada dua macam, pertama investasi aset riil seperti tanah, emas, dan bangunan. Kedua, investasi aset finansial meliputi saham, obligasi, dan deposito. Pada umumnya investasi aset finansial diperjualbelikan di pasar modal.

Menurut Undang-undang Pasar Modal Nomor 8 tahun 1995 berisi : "Pasar Modal yaitu sebagai suatu kegiatan yang bersangkutan dengan penawaran umum dan perdagangan efek, perusahaan publik yang berkaitan dengan efek yang diterbitkannya, 
serta lembaga dan profesi yang berkaitan dengan efek".

Analisis fundamental menggunakan laporan keuangan sebagai sarana informasi keuangan perusahaan. Mengaplikasikan analisis fundamental sebagai alat analisis sebelum berinvestasi adalah pilihan yang tepat karena laporan keuangan merupakan bentuk nyata untuk melihat kinerja perusahaan saat itu dan apa yang akan terjadi dengan harga saham perusahaan tersebut sesudah laporan keuangan dikeluarkan. Salah satu informasi yang diperlukan dari laporan keuangan adalah dengan mengetahui variabel-variabel apakah yang menjadi penyebab harga saham berfluktuasi. Salah satu indikator pengukuran harga saham yakni: Earning Per Share. Earnings Per Share (EPS) mengukur kemampuan perusahaan untuk menghasilkan keuntungan per lembar saham. Semakin tinggi (EPS) maka semakin mampu perusahaan tersebut untuk memberikan tingkat kesejahteraan yang baik untuk pemegang saham. Sedangkan rendahnya (EPS) menunjukan bahwa perusahaan tersebut gagal memberikan kemanfaatan sebagaimana yang diharapkan oleh investor.

Peneliti merumuskan masalah dalam penelitian ini yaitu, apakah earning per share secara parsial berpengaruh terhadap harga saham. Tujuan penelitian yaitu, untuk mengetahui apakah earning per share secara parsial berpengaruh terhadap harga saham.

\section{Earnings Per Share}

Earning per share (EPS) adalah jumlah yang diterima dalam suatu periode atas setiap lembar saham biasa yang beredar, dihitung dengan membagi total pendapatan suatu periode dibagi dengan jumlah saham biasa yang beredar (Gitman \& Zutter, 2014). Pada umumnya dalam menanamkan modalnya investor mengharapkan manfaat yang akan dihasilkan dalam bentuk laba per lembar saham (EPS). Laba per lembar saham (EPS) dapat menunjukan tingkat kesejahteraan perusahaan, jadi apabila laba per lembar saham (EPS) yang dibagikan kepada para investor tinggi maka menandakan bahwa perusahaan tersebut mampu memberikan tingkat kesejahteraan yang baik kepada pemegang saham, sedangkan laba per lembar saham (EPS) yang dibagikan rendah maka menandakan bahwa perusahaan tersebut gagal memberikan kemanfaatan sebagaimana diharapkan oleh pemegang saham. Adapun perhitungan EPS menurut Fahmi (2013) dapat dihitung dengan rumus seperti berikut:

$$
\text { EPS }=\frac{\text { Laba Bersih Setelah Pajak }}{\text { Jumlah Saham yang Beredar }}
$$




\section{Harga Saham}

Hunjra et al (2014) mengatakan bahwa, "Harga saham adalah harga dari saham tunggal dari sejumlah saham yang dapat dijual dari perusahaan, dan harga saham menjadi indikasi kekuatan perusahaan". Harga saham merupakan harga penutupan pasar saham selama periode pengamatan untuk tiap-tiap jenis saham yang dijadikan sampel dan pergerakannya senantiasa diamati oleh para investor.

\section{Perusahaan Manufaktur Sektor Barang}

\section{Konsumsi}

Perusahaan manufaktur adalah barang yang diproduksi dan dijual perusahaan tersebut. Penjualan produk tersebut akan menghasilkan penerimaan bagi perusahaan (Manalu, 2018).

Dengan banyaknya perusahaan yang ada di sektor manufaktur membuat sektor ini berperan penting bagi industri di Indonesia sehingga investor dapat menjadikan sektor manufaktur sebagai alternatif untuk berinvestasi. Sektor Industri Barang Konsumsi memberi dampak yang sangat berpengaruh dalam industri manufaktur dikarenakan sektor barang konsumsi selalu mengalami peningkatan dari tahun ke tahun. Hal ini dapat dibenarkan mengingat sektor barang konsumsi produknya adalah barang yang dikonsumsi sehari-hari baik investor maupun bukan investor dengan kata lain seluruh masyarakat. Di mana pun kita berada kita akan selalu bertemu dengan produk dari sektor barang konsumsi. Contohnya air mineral yang kita beli untuk minum, sabun, odol, rokok, dan masih banyak lagi. Untuk itu perusahaan manufaktur sektor barang konsumsi sangat menarik untuk menjadi objek penelitian.

\section{Metode Penelitian}

Penelitian ini berlokasi di Bursa Efek Indonesia. Penelitian ini merupakan penelitian kuantitatif dengan jenis penelitian yaitu penelitian asosiatif kausal.

Peneliti menganalisis pengaruh earning per share terhadap harga saham, dimana earning per share merupakan variabel independen atau variabel yang mempengaruhi, sedangkan harga saham merupakan variabel dependen yaitu variabel yang terpengaruh terhadap variabel independen (EPS). Sampel pada penelitian ini ditentukan dengan menggunakan teknik purposive sampling, yaitu teknik penentuan sampel berdasarkan kriteria tertentu dan sumber data yang digunakan adalah sumber data sekunder yang berasal dari laporan keuangan perusahaan yang diambil di situs resmi Bursa Efek Indonesia lebih khusus Earning Per Share dan Harga Saham penutupan kuartal IV. Adapun jumlah 
sampel yang sudah disaring menurut kriteria pengambilan sampel berjumlah 29.

\section{Hasil Penelitian}

\section{Analisis Deskriptif}

Pada hasil pengujian analisis deskriptif menunjukkan adanya kecenderungan Earning Per Share berpengaruh positif terhadap harga saham dilihat dari perusahaan yang Earning Per Share dan harga saham nya tinggi, terdapat lebih dari setengah yaitu sebanyak 15 perusahaan (rata-rata diambil dari jumlah sampel yaitu 29).

\section{Statistik Deskriptif}

Berdasarkan tabel statistik deskriptif hasil SPSS untuk statistik deskriptif variabel EPS menunjukkan sampel (N) sebanyak 29, yang diperoleh dari sampel Perusahaan Manufaktur Sektor Barang Konsumsi dikalikan dengan 4 tahun untuk tiap tahun penelitian.

\begin{tabular}{llccc}
\hline \multicolumn{5}{c}{ Tabel Statistik Deskriptif } \\
\hline & & & & \\
& N & Min & Max & Mean \\
EPS & 116 & -107 & 4,050 & 290.04 \\
Harga & 116 & 50 & 170,324 & $8,460.37$ \\
Saham & & & & \\
Valid N & & & & \\
(listwise) & 116 & & &
\end{tabular}

Pada tabel diatas, dari 29 sampel tersebut dapat dilihat bahwa hasil statistik deskriptif dari variabel independent Earning Per Share (EPS) memiliki nilai minimum -107 , nilai maksimum 4,050 dan nilai rata-rata Earning Per Share (EPS) yang positif menunjukkan rata-rata perusahaan manufaktur sektor barang konsumsi yang terdaftar di Bursa Efek Indonesia periode 2015-2018 mendapatkan laba, dengan rata-rata EPS-nya adalah 290,04 .

Hasil statistik deskriptif dari variabel independen Harga Saham memiliki nilai minimum 50, nilai maksimum 170,324 dan nilai rata-rata perusahaan tersebut mengalami kenaikan harga saham dengan rata-rata Harga Saham adalah 8,460 .

\section{Uji Asumsi Klasik}

\section{Uji Linieritas}

\begin{tabular}{|c|c|c|c|c|c|}
\hline \multicolumn{6}{|c|}{$\begin{array}{c}\text { Tabel Uji Linieritas } \\
\text { ANOVA }^{\text {a }}\end{array}$} \\
\hline Model & $\begin{array}{l}\text { Sum of } \\
\text { Squares }\end{array}$ & Df & $\begin{array}{c}\text { Mean } \\
\text { Square }\end{array}$ & $\mathrm{F}$ & Sig. \\
\hline $\begin{array}{ll}1 & \text { Regre } \\
\text { ssion }\end{array}$ & $\begin{array}{r}2577388 \\
5742.47 \\
1\end{array}$ & 1 & $\begin{array}{r}2577388574 \\
2.471\end{array}$ & $\begin{array}{r}87.70 \\
3\end{array}$ & $.000^{\mathrm{b}}$ \\
\hline $\begin{array}{l}\text { Resi } \\
\text { dual }\end{array}$ & $\begin{array}{r}3350203 \\
9640.59 \\
0\end{array}$ & $\begin{array}{r}11 \\
4\end{array}$ & $\begin{array}{r}293877540 . \\
707\end{array}$ & & \\
\hline Total & $\begin{array}{r}5927592 \\
5383.06 \\
0\end{array}$ & $\begin{array}{r}11 \\
5\end{array}$ & & & \\
\hline
\end{tabular}

Hasil output kelinieran garis regresi dapat dilihat dari nilai $\mathrm{F}$ dan Sig dalam kotak ANOVA. Untuk garis regresi linier ini lebih mudah menggunakan Sig. Persyaratan yang digunakan adalah nilai Sig. $>$ atau $=0,05$ (alpha yang sudah ditentukan) maka $\mathrm{H}_{0}$ diterima dan artinya persamaan garis regresi tidak linier dan 
apabila nilai Sig. $<0,05$ maka $\mathrm{H}_{0}$ ditolak dan artinya persamaan garis regresi linier.

Berdasarkan tabel hasil uji linieritas pada output tabel Anova diatas, diketahui bahwa nilai Sig. Devition From Liniearity sebesar 0.000. Karena nilai Sig. $<0,05$ maka dapat disimpulkan bahwa $\mathrm{H}_{0}$ ditolak, artinya terdapat hubungan linier variabel EPS dengan variabel Harga Saham.

\section{Uji Autokolerasi}

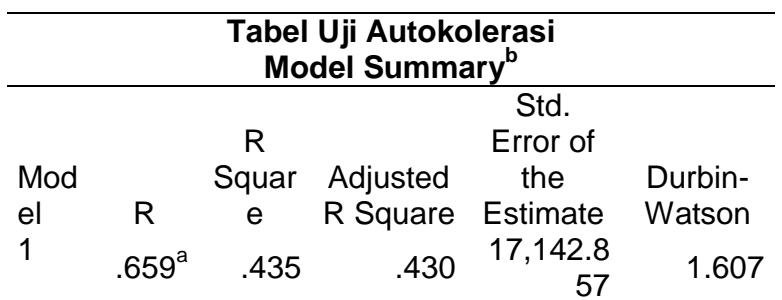

a. Predictors: (Constant), Earning Per Share

b. Dependent Variable: Harga Saham

Dari hasil perhitungan dalam tabel diatas bahwa diperoleh nilai DW sebesar 1.607 dan nilai ini akan dibandingkan dengan nilai tabel dengan menggunakan nilai signifikan 5\%. Berdasarkan kriteria pengambilan keputusan bahwa nilai DW diantara -2 sampai +2 , berarti tidak terjadi autokolerasi. Dengan demikian dapat disimpulkan tidak terjadi autokolerasi dalam model regresi ini.

\section{Analisis Regresi Linier Sederhana}

\begin{tabular}{lrrrrr}
\hline \multicolumn{6}{c}{ Tabel Uji Analisis Regresi Linier Sederhana } \\
Coefficients
\end{tabular}

a. Dependent Variable: Harga Saham

Diketahui nilai Constant (a) sebesar 2567.945 sedangkan nilai Earning Per Share (b/koefisien regresi) sebesar 20.316, sehingga persamaan regresinya dapat ditulis:

$\mathrm{Y}=\alpha+\beta 1 \mathrm{X}$

$Y=2567.945+20.316 X$

Persamaan tersebut dapat diterjemahkan:

- Konstanta sebesar 2567.945, mengandung arti bahwa nilai konsisten variabel Harga Saham adalah sebesar 2567.945

- Koefisien regresi X sebesar 20.316 menyatakan bahwa setiap penambahan 1\% nilai Earning Per Share maka nilai Harga Saham bertambah sebesar 2567.945. Koefisien regresi tersebut bernilai positif, sehingga dapat dikatakan bahwa arah pengaruh variabel $\mathrm{X}$ terhadap variabel $\mathrm{Y}$ adalah positif.

Berdasarkan persamaan tersebut Earning Per Share (EPS) menunjukan kemampuan perusahaan dalam menghasilkan keuntungan bersih dalam setiap lembar sahamnya. Semakin tinggi nilai Earning Per Share (EPS) berarti semakin baik karena akan meningkatkan harga saham dan ini akan menguntungkan perusahaan.

Perusahaan dengan nilai Earning Per Share (EPS) yang semakin tinggi akan 
menarik investor, sehingga semakin tinggi

Earning Per Share (EPS) suatu perusahaan berarti semakin tinggi pula harga sahamnya.

\section{Pengujian Hipotesis}

\section{Analisis Koefisien Determinasi $\left(\mathbf{R}^{\mathbf{2}}\right)$}

Berdasarkan tabel uji autokolerasi diatas, diketahui nilai koefisien determinasi atau $\mathrm{R}$ square adalah sebesar 0,435 . Nilai $\mathrm{R}$ square ini berasal dari pengkuadratan nilai koefisien korelasi atau " $R$ " yaitu 0,659 × $0,659=0,435$. Besarnya angka koefisien determinasi $\left(\mathrm{R}^{2}\right)$ adalah 0,435 atau sama dengan 43,5\%. Angka tersebut mengandung arti bahwa variabel EPS (X) berpengaruh terhadap variabel Harga Saham (Y) sebesar 43,5\%. Sedangkan sisanya $(100 \%-43,5 \%=56,5 \%)$ dipengaruhi oleh variabel lain diluar persamaan regresi ini atau variabel yang tidak diteliti.

Besarnya pengaruh variabel lain disebut juga sebagai error (e). Untuk menghitung nilai error tersebut kita dapat menggunakan rumus $\mathrm{e}=1-\mathrm{R}^{2}$. Besarnya nilai koefisien determinasi atau $\mathrm{R}$ square ini umumnya berkisar antara $0-1$. Namun demikian, jika dalam penelitian kita jumpai $\mathrm{R}$ square bernilai minus atau negatif (-), maka dapat dikatakan bahwa tidak terdapat pengaruh variabel $\mathrm{X}$ terhadap variabel $\mathrm{Y}$. Selanjutnya, semakin kecil nilai koefisien determinasi ( $\mathrm{R}$ square), maka ini artinya pengaruh variabel bebas (X) terhadap variabel terikat (Y) semakin lemah. Sebaliknya jika nilai $\mathrm{R}$ square semakin mendekati angka 1, maka pengaruh tersebut akan semakin kuat.

\section{Uji Statistik t (Uji Parsial)}

Berdasarkan tabel output SPSS pada tabel uji analisis regresi linier sederhana diatas diketahui nilai Signifikansi (Sig) variabel Earning Per Share (X) adalah sebesar 0,000. Karena nilai Sig. < probabilitas 0,05 maka dapat disimpulkan bahwa $\mathrm{H}_{1}$ atau hipotesis alternatif diterima. Artinya ada pengaruh signifikan positif terhadap Harga Saham.

Rumus untuk mencari t tabel :

$\mathrm{t}$ tabel $=(\mathrm{a} / 2 ; \mathrm{n}-\mathrm{k}-1)$ atau $\mathrm{t}$ tabel $=(\mathrm{a} / 2 ; \mathrm{df}$ residual)

$\mathrm{t}$ tabel $=(\mathrm{a} / 2 ; \mathrm{n}-\mathrm{k}-1)$

$\mathrm{t}$ tabel $=(0,05 / 2 ; 116-1-1)$

$\mathrm{t}$ tabel $=(0,025 ; 114)$

Berdasarkan tabel output SPSS "Coefficients" diatas diketahui nilai t hitung variabel motivasi adalah sebesar 9,365. Karena nilai t hitung 9,365 > t tabel 1,982, maka dapat disimpulkan bahwa $\mathrm{H}_{1}$ diterima atau hipotesis alternatif diterima. Artinya ada pengaruh signifikan positif terhadap Harga Saham. 
Nilai positif tersebut menunjukan pengaruh yang searah. Nilai Earning Per Share (EPS) menunjukan laba bersih perusahaan yang siap dibagikan kepada pemegang saham. Jika Earning Per Share (EPS) positif, maka Earning Per Share (EPS) akan semakin tinggi dan Harga Saham akan semakin mahal.

\section{Pembahasan}

Berdasarkan keseluruhan hasil uji data analisis penelitian, dapat dilihat bahwa variabel tingkat laba per lembar saham atau Earning Per Share (EPS) memiliki pengaruh secara parsial dan berpengaruh positif signifikan terhadap harga saham pada perusahaan manufaktur sektor barang konsumsi di Bursa Efek Indonesia. Hal ini menunjukkan bahwa informasi Earning Per Share (EPS) yang terdapat dalam laporan keuangan perusahaan merupakan hal yang paling utama diperhatikan oleh investor dalam membuat keputusan investasinya. Nilai Earning Per Share (EPS) yang meningkat menunjukkan bahwa jumlah laba yang dibagikan kepada investor semakin besar sehingga dengan meningkatnya Earning Per Share (EPS) ini akan menarik investor untuk membeli harga saham dengan permintaan saham yang meningkat, maka harga saham emiten juga akan ikut meningkat.
Dengan demikian Earning Per Share (EPS) berpengaruh positif secara signifikan terhadap harga saham. Atau dapat dikatakan tingkat jumlah uang (rupiah) yang dihasilkan dari setiap lembar saham biasa yang beredar semakin meningkat atau semakin besar, maka harga saham yang akan diterima investor juga akan semakin meningkat.

\section{Kesimpulan}

Berdasarkan hasil analisis data dan pembahasan yang sudah diuraikan dapat ditarik kesimpulan sebagai berikut.

Variabel Independen dalam hal ini Earning Per Share (EPS) secara parsial berpengaruh positif signifikan terhadap harga saham pada perusahaan manufaktur sektor barang konsumsi yang terdaftar di Bursa Efek Indonesia periode 2015-2018.

Hipotesa peneliti yang menduga terdapat pengaruh positif dan signifikan antara Earning Per Share (EPS) terhadap Harga Saham perusahaan manufaktur sektor barang konsumsi yang terdaftar di Bursa Efek Indonesia (BEI) tahun 2015 2018, dapat dibuktikan.

Ada banyak hal yang dapat mempengaruhi naik turunnya harga saham atau tinggi rendahnya harga saham. Earning Per Share (EPS) hanyalah salah satu dari sekian banyak faktor yang dapat mempengaruhi harga saham. Beberapa 
contoh hal-hal lain tersebut pada bab kajian teori.

\section{Saran}

Perusahaan harus memperhatikan nilai perusahaan melalui variabel-variabel yang berpengaruh terhadap harga saham. Beberapa variabel lain yang dapat dilihat dari laporan keuangan yang bisa memberi pengaruh terhadap harga saham seperti Dividend Per Share (DPS), Price Earning Ratio (PER), Debt to Equity Ratio (DER), Total Assets, Turn Over Ratio, atau Growth Potential.

Nilai perusahaan yang meningkat akan menarik minat investor untuk menanamkan modalnya pada perusahaan. Investor harus memperhatikan faktor internal dari perusahaan yang bersangkutan.

Bagi peneliti selanjutnya perlu menambah periode tahun penelitian dan menambah rasio keuangan lainnya yang diduga berpengaruh terhadap harga saham.

\section{Daftar Pustaka}

Fahmi, I. 2013. Analisis Laporan Keuangan. Bandung: Alfa beta.

Hunjra, A. I, Ijaz, M. S, Chani, M. I, Mustafa, U., \& Hassan, S. 2014. Impact of Dividend Policy, Earning Per Share, Return on Equity, Pro_t after Taxon Stock Price. International Journal of Economics
(3). Hal: 109-115.

Manalu, S. Stevi J. P. 2018. Cara Akurat Menyusun Penganggaran Perusahaan Manufaktur. Malang: CV. Seribu Bintang.

Tandelilin, E. 2010. Porto Folio dan Investasi. Yogyakarta: Kanisius. 